\title{
HEAT WAVES CHARACTERISTICS AND THEIR RELATION TO AIR QUALITY IN ATHENS
}

\author{
D.K. PAPANASTASIOU ${ }^{1, *}$ \\ D. MELAS ${ }^{2}$ \\ H.D. KAMBEZIDIS ${ }^{3}$
}

\author{
${ }^{1}$ Laboratory of Agricultural Engineering and Environment \\ Institute for Research and Technology - Thessaly \\ Centre for Research and Technology Hellas \\ Dimitriados St 95 \& Pavlou Mela St, GR-38333, Volos, Greece \\ ${ }^{2}$ Laboratory of Atmospheric Physics, School of Physics \\ Aristotle University of Thessaloniki, Campus Box 149, Thessaloniki, Greece \\ ${ }^{3}$ Atmospheric Research Team \\ Institute for Environmental Research \& Sustainable Development \\ National Observatory of Athens Lofos Nymphon, GR-11810 Athens, Greece
}

Received: 01/11/2012

Accepted: 01/10/2014

Available online: 03/10/2014 *to whom all correspondence should be addressed: e-mail:dkpapan@ireteth.certh.gr,dkpapan@auth.gr

\section{ABSTRACT}

This paper studies the characteristics of the heat waves that were observed in Athens, Greece since 1951. A heat wave is detected when two temperature criteria are fulfilled at the city centre: the daily maximum temperature value is at least $37^{\circ} \mathrm{C}$ and the daily average temperature value is at least $31{ }^{\circ} \mathrm{C}$. Information about the intensity, duration, timing in season and annual frequency of occurrence of heat waves were extracted. The slope of the linear fit of the annual number of heat wave days indicated that 1.30 more heat wave days per year were observed after 1992. The intensity and the duration of heat waves have also increased since 90s, while heat wave days have been detected during the whole summer since then, even during the first days of September. Additionally, air quality at the centre and at a suburb of Athens during the heat wave days that were identified during the last decade is examined. The daily average value of $\mathrm{PM}_{10}$ concentration exceeded $50 \mu \mathrm{g} \mathrm{m}^{-3}$ in $65 \%$ and $59 \%$ of the heat wave days at the urban and the suburban site, respectively, while the information and the alert $\mathrm{O}_{3}$ threshold were exceeded in $17 \%$ and $5 \%$ of the heat wave days, respectively, at the suburban site. The degradation of air quality during heat wave days is also verified by the means of the common air quality index. Moreover, it was found that $\mathrm{O}_{3}$ levels decrease when heat waves last more than 6 days.

Keywords: Heat wave, temperature, air quality, air pollution

\section{Introduction}

Heat waves are related to serious environmental and medical problems, generating also serious economic consequences (Matzarakis and Nastos, 2011). High temperatures can cause thermal stress and can worsen air quality. These conditions can trigger adverse health effects especially to the more vulnerable groups that include individuals suffering from cardiovascular or respiratory diseases and the elderly (Stafoggia et al., 2006). Nastos and Matzarakis (2008a) suggested that a considerable increase in sleep disturbances existed in 1994 compared to 1989, due to the many consecutive days with heavy thermal load in 1994 compared to the lack of such days in 1989. Additionally, heat waves can affect various other sectors including agriculture, livestock, fisheries, forests, construction and transportation 
(Fuhrer et al., 2006; Smoyer-Tomic et al., 2003). Moreover, the combination of high temperatures and drought can result in forest fires that contribute to the degradation of air quality and the reduction of carbon stocks (Vautard et al., 2007). Furthermore, heat waves induce significant increases in electricity demand for air conditioning (Miller et al., 2008), as the access to cool environments contributes to the reduction of heat related mortality (O'Neill et al., 2005).

Many studies that have been conducted worldwide underlined the relation between thermal stress and mortality. Giles et al., (1990) stated that more than 1,000 people died in Greece during the July 1987 heat wave. Nastos and Matzarakis (2009) analyzed the daily maximum and minimum air temperature, the daily temperature range and the daily values of thermal indices observed in Athens during the period $1992-2001$ and found that very hot conditions are risk factors for the daily mortality. Fouillet et al., (2006) reported that 15,000 excess deaths were observed during the August 2003 heat wave in France. Tan et al. (2007) reported that the maximum number of daily deaths during the July 2003 heat wave in Shanghai was $42 \%$ more than the non-heat day average. Vaneckova et al., (2008) reviewed some physiological and social factors that have also been found to contribute to higher incidence of heat-related deaths.

Air quality is worsened when high temperatures prevail (Papanastasiou et al., 2010; Struzewska and Kaminski, 2008; Theoharatos et al., 2010). $\mathrm{O}_{3}$ levels increase as photochemical processes are enhanced, the emission of biogenic organic compounds that may also affect ozone's chemistry is favoured and the production of secondary aerosols is also supported (Seinfeld and Pandis, 1998). Additionally, pollution levels can be further increased if atmospheric conditions that favour the accumulation of pollutants prevail during a heat wave (Tressol et al., 2008). Stagnation of air masses allows the accumulation of pollutants in the atmospheric boundary layer and in the residual layer during the night (Solberg et al., 2008). The combination of high pollution levels and high temperatures has been implicated to increase discomfort conditions and health risks. Paliatsos and Nastos (1999) found that during the days of the warm period of the year when pollution levels were high, more than $50 \%$ of the population in the greater Athens area feels discomfort from 10:00 to 19:00 LST. Fischer et al. (2004) showed that 400 600 deaths occurred during the 2003 heat wave in the Netherlands could be attributed to $\mathrm{O}_{3}$ and $\mathrm{PM}_{10}$ exposure. Filleul et al., (2006) found that the excess risk of deaths linked to $\mathrm{O}_{3}$ and temperature together during the August 2003 heat wave in France ranged from $10.6 \%$ in Le Havre to $174.7 \%$ in Paris. Stafoggia et al., (2008) estimated that a $10 \mu \mathrm{g} \mathrm{m}^{-3}$ increase in $\mathrm{PM}_{10}$ concentration results in a $2.54 \%$ and $0.20 \%$ rise in risk of death in summer and winter, respectively.

As the adverse health effects of heat waves are largely preventable, heat-health action plans could be developed and implemented at national and regional levels in Europe to prevent, react upon and contain heat related risks to health (Matthies and Menne 2009; Michelozzi et al., 2007). These plans could exploit meteorological and air quality early warning systems (Moustris et al., 2010; Vouterakos et al., 2012).

The objective of this paper is to identify the characteristics of the heat waves that have been observed in Greece since 1951 and to assess the air quality in Athens during the heat waves that occurred in the last decade.

\section{Materials and methods}

Temperature data recorded at the centre of Athens (Thissio, National Observatory of Athens) and air pollution data $\left(\mathrm{PM}_{10}, \mathrm{NO}_{2}, \mathrm{O}_{3}\right)$ recorded at the city centre (Aristotelous station) and at a suburban site (Lykovrisi station) were used in this study. Both air pollution stations are members of the national network of air pollution monitoring. $\mathrm{PM}_{10}$ and $\mathrm{NO}_{2}$ concentrations were monitored in both sites, while $\mathrm{O}_{3}$ was observed only at Lykovrisi. The temperature archive includes daily maximum and daily minimum temperature values recorded during the period $1951-2010$, while the air pollution archive includes hourly pollutants' concentrations monitored during the period $2001-2010$. 
The identification of a heat wave day was based on two temperature criteria that have been suggested by Metaxas and Kallos (1980): the daily maximum and the daily average temperature value at the city centre are at least $37^{\circ} \mathrm{C}$ and $31^{\circ} \mathrm{C}$, respectively. The daily average temperature value for each day was set equal to the average of the daily maximum and the daily minimum temperature value. The number of the identified heat wave days could be slightly different if the daily average temperature value was calculated using the hourly temperature values.

Air quality ( $\mathrm{PM}_{10}$ and $\mathrm{O}_{3}$ concentration levels) during heat wave days was assessed (i) taking into account the European Union's regulations in force (Directive 2008/50) and (ii) by the means of the common air quality index (CAQI). Directive 2008/50 states that the daily average value of $\mathrm{PM}_{10}$ concentration should not exceed $50 \mu \mathrm{g} \mathrm{m}^{-3}$ on more than 35 days per year and also sets information $\left(180 \mu \mathrm{g} \mathrm{m}^{-3}\right)$ and alert $\left(240 \mathrm{\mu g} \mathrm{m}^{-3}\right.$ ) thresholds for hourly $\mathrm{O}_{3}$ concentration. CAQI was developed under CITEAIR project (Van den Elshout et al., 2008) and has also been applied in other relevant studies (Poupkou et al., 2011). It is calculated according to a grid (Table 1), by linear interpolation between the class borders. The final index is the highest value of the sub-indices for each component. Two CAQIs have been proposed: one for traffic monitoring sites that comprises $\mathrm{PM}_{10}$ and $\mathrm{NO}_{2}$ concentrations and one for urban background sites that comprises $\mathrm{PM}_{10}, \mathrm{NO}_{2}$ and $\mathrm{O}_{3}$ concentrations. Both indices were used in this study. As CAQI was used for a daily index, the daily average value of $\mathrm{PM}_{10}$ concentration and the daily maximum hourly value of $\mathrm{NO}_{2}$ and $\mathrm{O}_{3}$ concentration were used in this study.

Table 1. Calculation grid for the CAQI

\begin{tabular}{ccccc}
\hline \multirow{2}{*}{ Index class } & \multirow{2}{*}{ Grid } & \multicolumn{3}{c}{ Concentration class $\left(\mu \mathrm{g} \mathrm{m}^{-3}\right)$} \\
\cline { 3 - 5 } & & $\mathrm{PM}_{10}$ & $\mathrm{NO}_{2}$ & $\mathrm{O}_{3}$ \\
\hline Very low & $0-25$ & $0-12$ & $0-50$ & $0-60$ \\
\hline Low & $26-50$ & $13-25$ & $51-100$ & $61-120$ \\
\hline Medium & $51-75$ & $26-50$ & $101-200$ & $121-180$ \\
\hline High & $76-100$ & $51-100$ & $201-400$ & $181-240$ \\
\hline Very high & $>100$ & $>100$ & $>400$ & $>240$ \\
\hline
\end{tabular}

\section{Results and discussion}

\subsection{Characteristics of heat waves}

The number of heat wave days and the number of heat wave events that were identified per year during the period $1951-2010$ are shown in figure 1 . This figure reveals that few heat wave days were identified until the mid 60s. Their higher annual number was observed in 1958 (i.e. 5 heat wave days). Taking also into account the number of the heat wave events that were identified until the mid $60 \mathrm{~s}$, it is revealed that the heat wave days were observed isolated or in two consecutive days. Exceptions are years 1957 and 1958 when 4 and 5 heat waves days, respectively, were observed consecutively, all detected in 1 heat wave event per year. Afterwards and until 1984, a negligible number of heat wave days were detected. The most significant heat wave event since 1951 was observed in 1987 when the heat wave day selection criteria were met during 8 consecutive days, while 4 consecutive heat wave days were also detected in years 1985 and 1988 (Giles and Balafoutis, 1990). No heat wave days were identified in years $1990-1992$. The situation is totally reversed after 1992 as a clear increasing trend is detected afterwards. The slope of the linear fit denotes that 1.30 more heat wave days per year were observed. The higher number of heat wave days during the examined period was observed in 2007, when 39 heat wave days were detected. The summer of 2007 was very likely the warmest summer at NOA's instrumental history (Founda and Giannakopoulos, 2009) and was exceptionally hot for southeastern Europe (Cheval et al., 2009). An upward trend is also detected in the annual number of the heat wave events after 1992 (figure 1), the slope being 0.45 . This fact indicates that the number of consecutive heat wave days has increased year by year, a conclusion that is also verified by figure $2 \mathrm{~b}$. Similar results regarding the temporal variation of the heat waves in Mediterranean during the last 
decades are reported by two other studies. Baldi et al. (2006) analyzed surface temperature data collected in fifty stations in Italy. They found that the heat waves are almost absent in the 70s, while they detected an impressive warming in the last decade of the $20^{\text {th }}$ century. They identified 187 heat wave days in the period $1991-2000$, which account for the $46 \%$ of the total number of heat wave days identified in the last half century. Nastos and Matzarakis (2008b) studied the variability of the tropical days (i.e. days with a maximum air temperature greater than $30.0^{\circ} \mathrm{C}$ ) over Greece within the second half of the twentieth century. The time series of the annual number of tropical days for the NOA revealed that the fewer tropical days were observed in 1976 and that a significant positive trend appeared after 1976 until the end of the examined period.

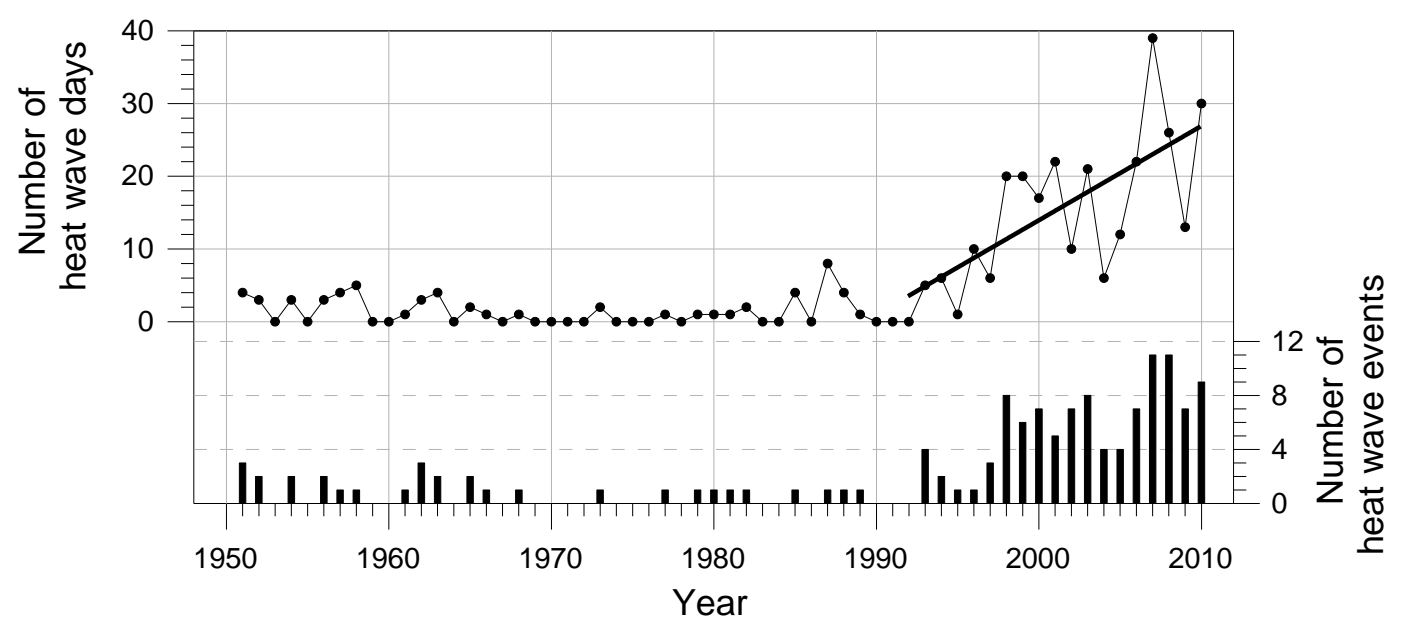

Figure 1. Number of identified heat wave days (solid curve with black circles) and heat wave events (bars) during the period $1951-2010$. Black line: linear fit
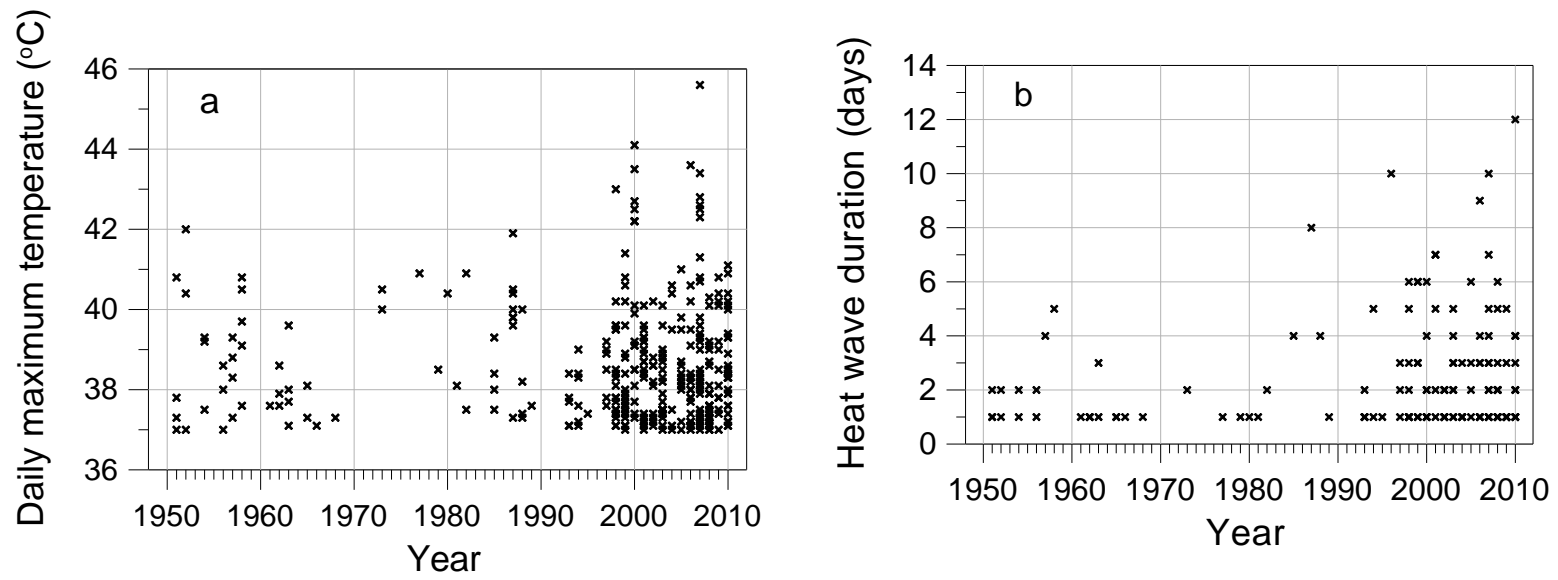

Figure 2. Intensity (a) and duration (b) of the heat waves observed during the period $1951-2010$

The daily maximum temperature values that were recorded during the identified heat wave days are plotted in figure 2a. It is shown that peak temperatures higher than $42{ }^{\circ} \mathrm{C}$ were observed after year 1998. Abaurrea et al., (2007) analyzed temperature data collected during the period 1951-2004 at the northeast of Spain and also found that the increase of the daily maximum temperature became more important after 1994. However, high temperatures, for example higher than $40{ }^{\circ} \mathrm{C}$ were observed in Athens during the whole examined period. On the contrary, the duration of the heat wave events started to increase in 90 s (figure $2 \mathrm{~b}$ ). The most prolonged heat wave event was observed in 2010, when 12 consecutive days were identified as heat wave days. The first long heat wave event was observed in 1987 and lasted 8 days. An increase of the heat wave duration, as well as an increase of the heat wave 
frequency of occurrence, was also detected by Unkašević and Tošić (2011) during the period 1999 2007, who studied the characteristics of the heat waves that were observed in central Serbia during the period $1949-2007$.

Figure 3 shows that during the last two decades summer is more uniformly hotter than before and the period prone to heat wave occurrence is longer. The heat wave days until the mid 60s were observed in July and August, the longer events being observed in August. The more important events during 80s were observed in July. During the last two decades, heat wave days were spread in the whole summer. Similar results are presented by Abaurrea et al., (2007). Based on summer data, they reported that July is the month most prone to have heat waves at the north-eastern Spain, followed by August and, finally, June. However, they underlined that this pattern disappears in $90 \mathrm{~s}$ due to the increase of the temperature in June. It is noticeable that the present study reveals that heat wave days have also been observed during the first days of September since 2003.

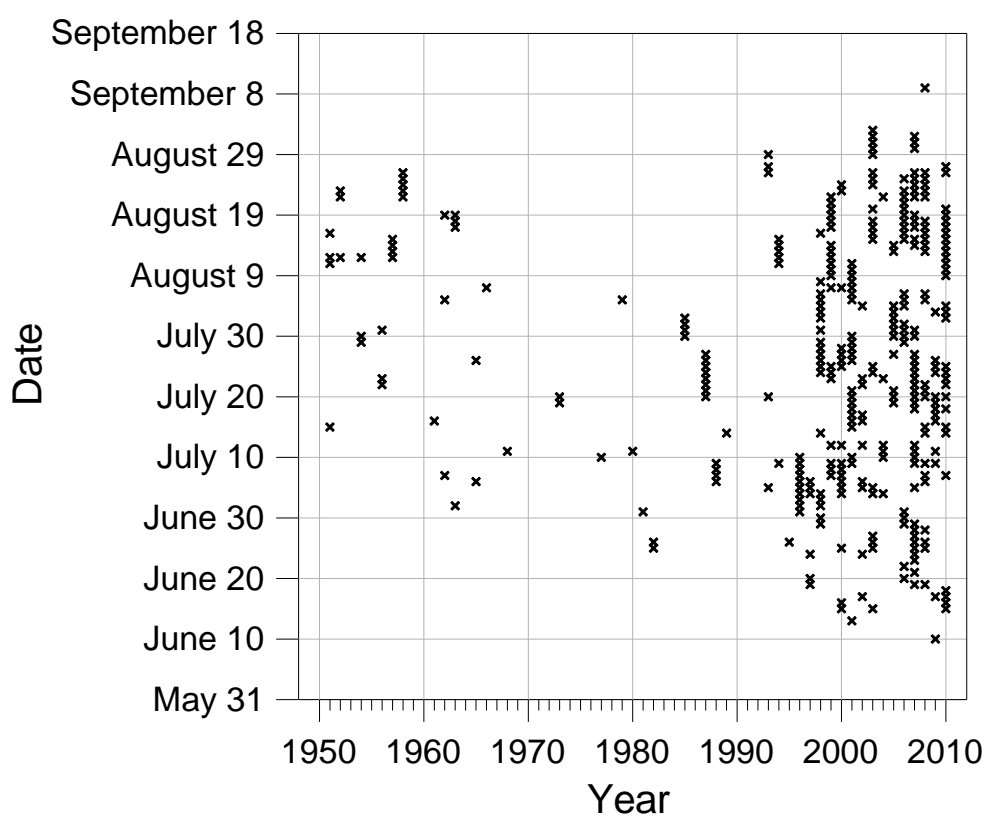

Figure 3. Dates during the period $1951-2010$ when the heat wave days occurred

\subsection{Assessment of air quality during heat waves}

Air pollution levels during the heat wave days that were identified during the last decade were studied. Air quality at the city centre and at a city suburb was assessed taking into account the European Union's regulations in force (Directive 2008/50) and by the means of CAQI. Table 2 presents the number of heat wave days per year when the air quality standards established for $\mathrm{PM}_{10}$ and $\mathrm{O}_{3}$ were exceeded. 201 heat wave days were identified during the period $2001-2010$. $\mathrm{PM}_{10}$ air quality standard was exceeded in 130 and 118 of them at Aristotelous and Lykovrisi, respectively, while the information and the alert $\mathrm{O}_{3}$ threshold were exceeded in 35 and 10 heat wave days, respectively, at Lykovrisi. These days correspond to the $65 \%, 59 \%, 17 \%$ and $5 \%$ of the total number of heat wave days. The higher number of exceedances was observed in 2007, when the higher number of heat wave days was also identified. In 2007, the daily average value of $\mathrm{PM}_{10}$ concentration remained over $50 \mu \mathrm{g} \mathrm{m}^{-3}$ during 27 and 28 heat wave days at Aristotelous and Lykovrisi, respectively, and the daily maximum hourly value of $\mathrm{O}_{3}$ concentration surpassed the information threshold during 8 heat wave days at Lykovrisi. Consequently, the air quality standard for $\mathrm{PM}_{10}$ concentration was violated in $69 \%$ and $72 \%$ of the total heat wave days at the urban and the suburban site, respectively, while the air quality standard for $\mathrm{O}_{3}$ concentration was violated in $21 \%$ of the total heat wave days at the suburban site.

The annual number of the excedances of the air quality standards correlates well with the annual number of heat wave days. This fact could be attributed to the atmospheric conditions that usually 
prevail during heat wave days. Stagnation of air masses is usually observed during heat waves (Tressol et al., 2008; Vautard et al., 2007), favouring the accumulation of particles and $\mathrm{O}_{3}$ precursors. Additionally, as heat waves usually occur under anticyclonic conditions (Katsoulis and Hatzianastassiou, 2005), the development of sea breeze is favoured. Sea breeze is considered to increase near surface pollution levels in Athens (Kambezidis et al., 1998; Larissi et al., 2010; Melas and Kambezidis, 1992). Moreover, hot weather in Mediterranean could be sometimes induced by the transport of hot air masses from North Africa (Theoharatos et al., 2010) that are rich in dust. Dust transport events frequently occur in Greece during summer (Papanastasiou et al., 2010; Papayannis et al., 2005), triggering an increase in $\mathrm{PM}_{10}$ levels (Kaskaoutis et al., 2008; Katragkou et al., 2009). The correlation coefficient between the annual number of heat wave days and the annual number of the exceedances of $\mathrm{PM}_{10}$ air quality standard at Aristotelous and Lykovrisi during heat wave days and the annual number of the exceedances of ozone's information threshold at Lykovrisi during heat wave days was found equal to $0.92,0.73$ and 0.62 , respectively. The correlation coefficient becomes lower at Lykovrisi compared to Aristotelous, as the impact of background pollution levels, which are less influenced by weather changes, is more pronounced there than at the city centre (Kalabokas and Repapis, 2004; Kalabokas et al., 2010).

Table 2. Annual exceedances of the $\mathrm{PM}_{10}$ and $\mathrm{O}_{3}$ air quality standards and air quality assessment by the means of CAQI during heat wave days at the urban and the suburban site

\begin{tabular}{|c|c|c|c|c|c|c|c|}
\hline \multirow{4}{*}{ Year } & \multicolumn{4}{|c|}{ Air quality standard } & \multicolumn{3}{|c|}{ CAQI class } \\
\hline & \multirow{2}{*}{\multicolumn{2}{|c|}{$\begin{array}{l}\text { Daily average value of } \\
\mathrm{PM}_{10} \text { concentration }\end{array}$}} & \multicolumn{2}{|c|}{$\mathrm{O}_{3}$ threshold } & \multirow{2}{*}{\multicolumn{2}{|c|}{ High }} & \multirow{3}{*}{$\begin{array}{c}\text { Very High } \\
\text { LYK }\end{array}$} \\
\hline & & & \multirow{2}{*}{$\begin{array}{c}\text { information } \\
\text { LYK }\end{array}$} & \multirow{2}{*}{$\begin{array}{l}\text { alert } \\
\text { LYK }\end{array}$} & & & \\
\hline & ARI & LYK & & & ARI & LYK & \\
\hline 2001 & 19 & 19 & 4 & 3 & 19 & 16 & 3 \\
\hline 2002 & 1 & 7 & 1 & 0 & 1 & 5 & 2 \\
\hline 2003 & 14 & 18 & 4 & 0 & 14 & 17 & 0 \\
\hline 2004 & 3 & 5 & 0 & 0 & 3 & 4 & 1 \\
\hline 2005 & 10 & 9 & 4 & 3 & 9 & 6 & 3 \\
\hline 2006 & 17 & 11 & 1 & 0 & 17 & 10 & 1 \\
\hline 2007 & 27 & 28 & 8 & 1 & 20 & 19 & 10 \\
\hline 2008 & 19 & 12 & 6 & 2 & 19 & 14 & 2 \\
\hline 2009 & 5 & 2 & 5 & 1 & 5 & 5 & 1 \\
\hline 2010 & 15 & 7 & 2 & 0 & 15 & 8 & 0 \\
\hline
\end{tabular}

The degradation of air quality during heat wave days is also verified by the CAQI values (table 2). Air pollution was "high" during 122 and 104 heat wave days at Aristotelous and Lykovrisi, respectively, and "very high" during 23 heat wave days at Lykovrisi. These values correspond to the $61 \%, 52 \%$ and $11 \%$ of the total heat wave days. Air pollution was "very high" during 7 heat wave days at Aristotelous, all of them detected in 2007. The annual frequency of occurrence of CAQI classes during heat wave days also correlates well with the annual number of heat wave days. The correlation coefficient between the annual number of heat wave days and the annual frequency of occurrence of class "high" during heat wave days at Aristotelous and Lykovrisi and the class "very high" during heat wave days at Lykovrisi was $0.86,0.77$ and 0.54 , respectively.

The heat wave events were classified according to their duration. The mean value of the daily average $\mathrm{PM}_{10}$ concentrations and the mean value of the daily maximum $\mathrm{O}_{3}$ concentrations that were recorded during the heat wave days included in every duration class were calculated. The results are presented in figure 4. This figure shows that pollution levels are not monotonous increasing as heat wave duration increases. A unimodal distribution is detected that is clearer for $\mathrm{O}_{3}$. It is revealed that mean $\mathrm{O}_{3}$ levels 
decrease when the heat wave event lasts more than 6 consecutive days. This reduction could be attributed to ozone's destruction and deposition processes, as well as to changes of the synoptic atmospheric conditions. Rao et al. (2003) analyzed $\mathrm{O}_{3}$ data observed in summer 1995 at two elevated platforms ( $\sim 400 \mathrm{~m} \mathrm{agl}$ ) in Garner, NC, and Chicago, IL, and found that $\mathrm{O}_{3}$ can persist for about $2-3$ days aloft before NO titration and deposition processes remove it. Additionally, Rao (1988) used surface $\mathrm{O}_{3}$ data recorded during the summer months of 1981 and 1983 in New Jersey and Connecticut and showed that once the surface $\mathrm{O}_{3}$ level exceeds $80 \mathrm{ppb}$, the probability of that exceedance lasting for $2-3$ days is very high. Moreover, Beaver et al. (2008) found that synoptic transitions can force changes of $\mathrm{O}_{3}$ levels. It is obvious that the onset and the cessation of a heat wave event coincide with a change in the prevailing synoptic atmospheric regime (Katsoulis and Hatzianastassiou, 2005).

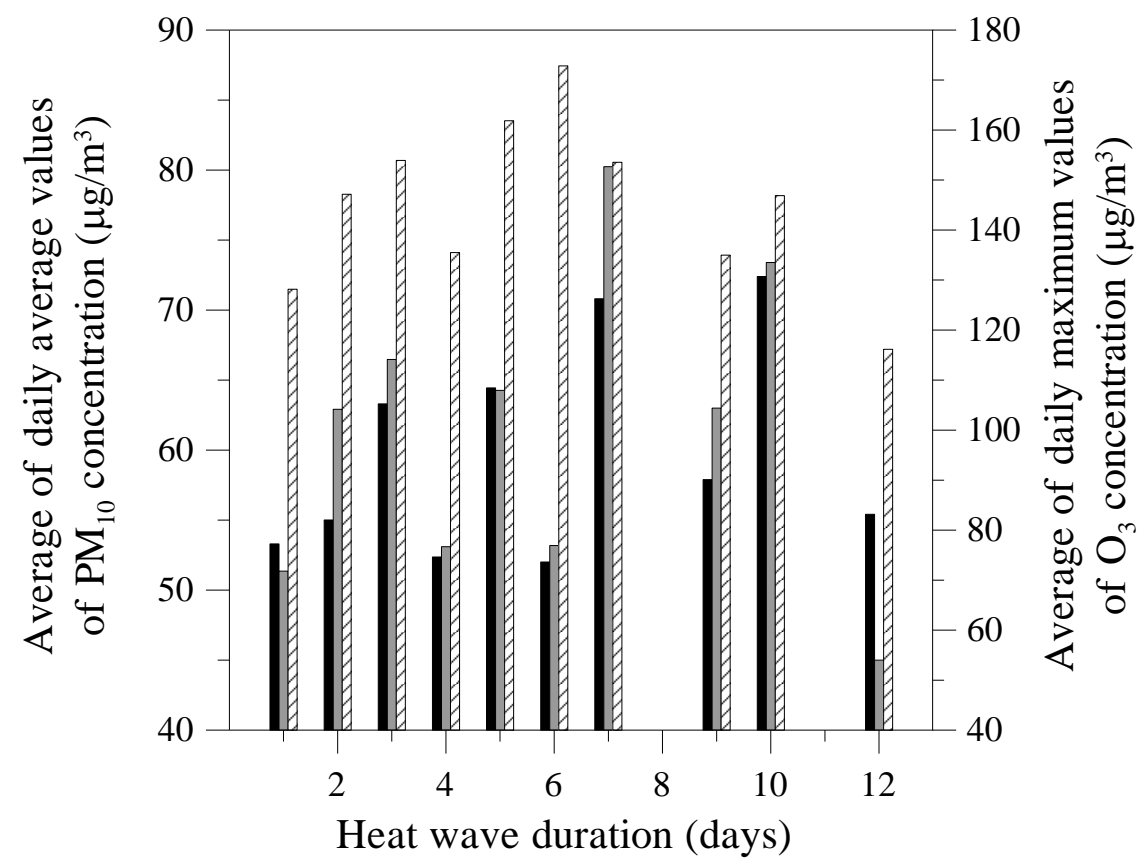

Figure 4. $\mathrm{PM}_{10}$ and $\mathrm{O}_{3}$ levels in relation to heat wave duration (black and grey bars: $\mathrm{PM}_{10}$ at Aristotelous and Lykovrisi, respectively; hatched bars: $\mathrm{O}_{3}$ at Lykovrisi).

\section{Conclusions}

The annual number of heat wave days and the annual number of heat wave events exhibit an upward trend after 1992 in Athens. A mean value of 1.30 more heat wave days per year was estimated. The more heat wave days during the period $1951-2010$ were detected in 2007, a fact that verifies that the summer of 2007 was the warmest summer for Athens in the last century. The peak temperature values also increased after $90 \mathrm{~s}$, exceeding $42{ }^{\circ} \mathrm{C}$. The duration of the heat waves started to increase in the beginning of 90s. The most prolonged heat wave was a 12-day event that was observed in 2010. During the last two decades, summer is more uniformly hotter than before and the period prone to heat wave occurrence is longer, extending from approximately the mid of June to the beginning of September.

Air quality was deteriorated during the heat wave days that were identified in the last decade. The air quality standards in force regarding the $\mathrm{PM}_{10}$ and $\mathrm{O}_{3}$ concentration were frequently violated. The annual number of exceedances correlates well to the annual number of heat wave days, a fact that could be attributed to the atmospheric conditions that usually prevail during heat wave days, which favour the increase of pollution levels. The application of CAQI showed that air pollution was high in $61 \%$ and $52 \%$ of the heat wave days at the urban and the suburban site, respectively and very high in $11 \%$ of the heat wave days at the suburban site. The variation of average pollution levels in relation with heat wave 
duration exhibited a peak that is more pronounced for $\mathrm{O}_{3}$. Mean $\mathrm{O}_{3}$ levels were higher during 6-day events.

\section{Acknowledgment}

The research has been co-financed by the European Union (European Regional Development Fund) and Greek national funds through the Operational Program "Competitiveness and Entrepreneurship" of the National Strategic Reference Framework (NSRF) - Research Funding Program COOPERATION 2009 (no 09COP-31-1094, Title "Development of a Geographic Climate Information System").

\section{References}

Abaurrea J., Asín J., Cebrián A.C. and Centelles A. (2007), Modeling and forecasting extreme hot events in the central Ebro valley, a continental-Mediterranean area, Global Planet. Change, 57, 43-58.

Baldi M., Dalu G., Maracchi G., Pasqui M. and Cesarone F. (2006), Heat waves in the Mediterranean: a local feature or a larger-scale effect?, Int. J. Climatol., 26, 1477-1487.

Beaver S., Palazoglu A. and Tanrikulu S. (2008), Cluster sequencing to analyze synoptic transitions affecting regional ozone, J. Appl. Meteorol. Clim., 47, 901-916.

Cheval S., Dumitrescu A. and Bell A. (2009), The urban heat island of Bucharest during the extreme high temperatures of July 2007, Theor. Appl. Climatol., 97, 391-401.

Filleul L., Cassadou S., Medina S., Fabres P., Lefranc A., Eilstein D., Le Tertre A., Pascal L., Chardon B., Blanchard M., Declercq C., Jusot J.-F., Prouvost H. and Ledrans M. (2006), The relation between temperature, ozone, and mortality in nine French cities during the heat wave of 2003, Environ. Health Persp., 4, 1344-1347.

Fischer P.H., Brunekreef B. and Lebret E. (2004), Air pollution related deaths during the 2003 heat wave in the Netherlands, Atmos. Environ., 38, 1083-1085.

Fouillet A., Rey G., Laurent F., Pavillon G., Bellec S., Guihenneuc-Jouyaux C., Clavel J., Jougla E. and Hémon D. (2006), Excess mortality related to the August 2003 heat wave in France, Int. Arch. Occ. Env. Hea., 80, 16-24.

Founda D. and Giannakopoulos C. (2009), The exceptionally hot summer of 2007 in Athens, Greece - A typical summer in the future climate?, Global Planet. Change, 67, 227-236.

Fuhrer J., Beniston M., Fischlin A., Frei C., Goyette S., Jasper K. and Pfister C. (2006), Climate risks and their impact on agriculture and forests in Switzerland, Climatic Change, 79, 79-102.

Giles B.D. and Balafoutis C.H. (1990), The Greek heatwaves of 1987 and 1988, Int. J. Climatol., 10, 505-517.

Giles B.D., Balafoutis C. and Maheras P. (1990), Too hot for comfort: the heatwaves in Greece in 1987 and 1988, Int. J. Biometeorol., 34, 98-104.

Kalabokas P.D. and Repapis C.C. (2004), A climatological study of rural surface ozone in central Greece, Atmos. Chem. Phys., 4, 1139-1147.

Kalabokas P.D., Adamopoulos A.D. and Viras L.G. (2010), Atmospheric $\mathrm{PM}_{10}$ particle concentration measurements at central and peripheral urban sites in Athens and Thessaloniki, Greece, Global Nest J., 12, 71-83.

Kambezidis H., Weidauer D., Melas D. and Ulbricht M. (1998), Air quality in the Athens basin during sea-breeze and non-sea-breeze days using laser remote sensing technique, Atmos. Environ., 32, 2173-2182.

Kaskaoutis D.G., Kambezidis H.D., Nastos P.T. and Kosmopoulos P.G. (2008), Study on an intense dust storm over Greece, Atmos. Environ., 42, 6884-6896.

Katragkou E., Kazadzis S., Amiridis V., Papaioannou V., Karathanasis S. and Melas D. (2009), PM 10 regional transport pathways in Thessaloniki, Greece, Atmos. Environ., 43, 1079-1085.

Katsoulis B.D. and Hatzianastassiou N. (2005), Analysis of hot spell characteristics in the Greek region, Clim. Res., 28, 229-241.

Larissi I.K., Antoniou A., Nastos P.T. and Paliatsos A.G. (2010), The role of wind in the configuration of the ambient air quality in Athens, Greece, Fresen. Environ. Bull., 19, 1989-1996.

Matthies F. and Menne B. (2009), Prevention and management of health hazards related to heat waves, Int. J. Circumpol. Heal., 68, 8-22. 
Matzarakis A. and Nastos P.T. (2011), Human-biometeorological assessment of heat waves in Athens, Theor. Appl. Climatol., 105, 99-106.

Melas D. and Kambezidis H.D. (1992), The depth of the Internal Boundary Layer over an urban area under sea breeze conditions, Bound.-Lay. Meteorol., 61, 247-264.

Metaxas D.A. and Kallos G. (1980), Heat waves from a synoptic point of view, Riv. Meteorol. Aeronaut., 40, $107-119$.

Michelozzi P., Kirchmayer U., Katsouyanni K., Biggeri A., McGregor G., Menne B., Kassomenos P., Anderson H.R., Baccini M., Accetta G., Analytis A. and Kosatsky T. (2007), Assessment and prevention of acute health effects of weather conditions in Europe, the PHEWE project: background, objectives, design, Environ. Health, 6:12, doi: 10.1186/1476-069X-6-12.

Miller N.L., Hayhoe K., Jin J. and Auffhammer M. (2008), Climate, extreme heat, and electricity demand in California, J. Appl. Meteorol. Clim., 47, 1834-1844.

Moustris K., Ziomas I.C. and Paliatsos A.G. (2010), 3-days ahead forecasting of regional pollution index for the pollutants $\mathrm{NO}_{2}, \mathrm{CO}, \mathrm{SO}_{2}$ and $\mathrm{O}_{3}$ using artificial neural networks in Athens, Greece, Water Air Soil Poll., 209, 29-43.

Nastos P.T. and Matzarakis A. (2008a), Human-biometeorological effects on sleep disturbances in Athens, Greece: A preliminary evaluation, Indoor Built Environ., 17, 535-542.

Nastos P.T. and Matzarakis A. (2008b), Variability of tropical days over Greece within the second half of the twentieth century, Theor. Appl. Climatol., 93, 75-89.

Nastos P.T. and Matzarakis A. (2011), The effect of air temperature and human thermal indices on mortality in Athens, Theor. Appl. Climatol., 108, 591-599.

O'Neill M.S., Zanobetti A. and Schwartz J. (2005), Disparities by race in heat-related mortality in four US cities: the role of air conditioning prevalence, J. Urban Health, 82, 191-197.

Paliatsos A.G. and Nastos P.T. (1999), Relation between air pollution episodes and discomfort index in the greater Athens area, Greece, Global Nest J., 1, 91-97.

Papanastasiou D.K., Amiridis V., Georgoulias A.K., Mamouri R.E. and Melas D. (2010), Impact of boundary layer evolution on near surface air pollution levels, $10^{\text {th }}$ International Conference on Meteorology, Climatology and Atmospheric Physics, May 25 - 28 2010, Patras, Greece.

Papanastasiou D.K., Melas D., Bartzanas T. and Kittas C. (2010), Temperature, comfort and pollution levels during heat waves and the role of sea breeze, Int. J. Biometeorol., 54, 307-317.

Papanastasiou D.K., Poupkou A., Katragkou E., Amiridis V., Melas D., Mihalopoulos N., Basart S., Pérez C. and Baldasano J.M. (2010), An assessment of the efficiency of dust regional modelling to predict Saharan dust transport episodes, Adv. Meteorol., vol. 2010, Article ID 154368, 9 pages, doi:10.1155/2010/154368.

Papayannis A., Balis D., Amiridis V., Chourdakis G., Tsaknakis G., Zerefos C., Castanho A.D.A., Nickovic S., Kazadzis S. and Grabowski J. (2005), Measurements of Saharan dust aerosols over the Eastern Mediterranean using elastic backscatter-Raman lidar, spectrophotometric and satellite observations in the frame of the EARLINET project, Atmos. Chem. Phys., 5, 2065-2079.

Poupkou A., Nastos P., Melas D. and Zerefos C. (2011), Climatology of discomfort index and air quality index in a large urban Mediterranean agglomeration, Water Air Soil Poll., 222, 163-183.

Rao S.T. (1988), Prepared discussion: Ozone air quality models, JAPCA, 38, 1129-1135.

Rao S.T., Ku J.Y., Berman S., Zhang K.S. and Mao H.T. (2003), Summertime characteristics of the atmospheric boundary layer and relationships to ozone levels over the eastern United States, Pure Appl. Geophys., 160, 21-55.

Seinfeld J.H. and Pandis S.N. (1998), Atmospheric chemistry and physics. From air pollution to climate change, Wiley.

Smoyer-Tomic K.E., Kuhn R. and Hudson A. (2003), Heat wave hazards: an overview of heat wave impacts in Canada, Nat. Hazards, 28, 463-485.

Solberg S., Hov O., Sovde A., Isaksen I.S.A., Coddeville P., De Backer H., Forster C., Orsolini Y. and Uhse K. (2008), European surface ozone in the extreme summer 2003, J. Geophys. Res., 113, D07307, doi:10.1029/2007JD009098. 
Stafoggia M., Forastiere F., Agostini D., Biggeri A., Bisanti L., Cadum E., Caranci N., de'Donato F., De Lisio S., De Maria M., Michelozzi P., Miglio R., Pandolfi P., Picciotto S., Rognoni M., Russo A., Scarnato C. and Perucci C.A. (2006), Vulnerability to heat-related mortality: a multicity, population-based, case-crossover analysis, Epidemiology, 7, 315-323.

Stafoggia M., Schwartz J., Forastiere F., Perucci C.A. and SISTI Group (2008), Does temperature modify the association between air pollution and mortality? A multicity case-crossover analysis in Italy, Am. J. Epidemiol., 167, 1476-1485.

Struzewska J. and Kaminski J.W. (2008), Formation and transport of photooxidants over Europe during the July 2006 heat wave - observations and GEM-AQ model simulations, Atmos. Chem. Phys., 8, 721-736.

Tan J., Zheng Y., Song G., Kalkstein L.S., Kalkstein A.J. and Tang X. (2007), Heat wave impacts on mortality in Shanghai, 1998 and 2003, Int. J. Biometeorol., 51, 193-200.

Theoharatos G., Pantavou K., Mavrakis A., Spanou A., Katavoutas G., Efstathiou P., Mpekas P. and Asimakopoulos D. (2010), Heat waves observed in 2007 in Athens, Greece: Synoptic conditions, bioclimatological assessment, air quality levels and health effects, Environ. Res., 110, 152-161.

Tressol M., Ordonez C., Zbinden R., Brioude J., Thouret V., Mari C., Nedelec P., Cammas J.-P., Smit H., Patz H.-W., and Volz-Thomas A. (2008), Air pollution during the 2003 European heat wave as seen by MOZAIC airliners, Atmos. Chem. Phys., 8, 2133-2150.

Unkašević M. and Tošić I. (2011), The maximum temperatures and heat waves in Serbia during the summer of 2007, Climatic Change, 108, 207-223.

Van den Elshout S., Leger K. and Nussio F. (2008), Comparing urban air quality in Europe in real time A review of existing air quality indices and the proposal of a common alternative, Environ. Int., 34, 720-726.

Vaneckova P., Beggs P.J., deDear R.J. and McCracken K.W.J. (2008), Effect of temperature on mortality during the six warmer months in Sydney, Australia, between 1993 and 2004, Environ Res, 108, 361-369.

Vautard R., Beekmann M., Desplat J., Hodzic A. and Morel S. (2007), Air quality in Europe during the summer of 2003 as a prototype of air quality in a warmer climate, Comptes Rendus Geoscience, 339, 747-763.

Vouterakos P.A., Moustris K.P., Bartzokas A., Ziomas I.C., Nastos P.T. and Paliatsos A.G. (2012), Forecasting the discomfort levels within the greater Athens area, Greece using artificial neural networks and multiple criteria analysis, Theor. Appl. Climatol., 110, 329-343. 